and his family and Daniel Williams, the library that came to bear the latter's name is a most fitting eventual home for Juxon's journal.

\title{
The joumal
}

Its format The manuscript is more accurately described as a journal rather than a diary in the conventional sense of a daily record of events, thoughts and reactions with a strong personal flavour. Except for the brief note about his marriage, there is nothing of a personal and private nature, nor do more mundane matters, such as his social calendar, feature at all. Juxon uses the first person singular just twice in the whole work (once when clarifying a statement and secondly when referring to his marriage), preferring instead to use the first person plural when not using impersonal forms of speech. His focus is almost exclusively on public affairs and political and military developments, and his perspective switches backwards and forwards between the City of London, the English parliament, Scotland and (to a much lesser degree) Ireland, and continental Europe. ${ }^{69}$ It is a work of both description and analysis, showing developments within the different political arenas as interacting with one another under the watchful eye of a providential God, who could be expected to intervene to mould events when the need arose. In short, it is a major work of historical discourse in which periodic divine intervention is taken as axiomatic.

The narrative generally keeps to a chronological order, although Juxon's original text rarely provides consistently clear guidance as to dating. This can often be imprecise and has a tendency to leave it to the reader to furnish exact dates. There are at least twenty-nine dating errors in the journal, the vast majority giving the correct month but wrong day, and most of the latter are out by one day only. Juxon regularly halts his narrative, or sometimes inserts marginalia, to provide an analysis of the current situation, draw conclusions from events or developments, point up a moral, or record the beneficent intervention of God. He is quite consciously addressing an intelligent and, he assumes, sympathetic readership, and the text may well have been an initial draft of a work intended for eventual publication. This might explain his habit in the first thirty-nine folios of including reference numbers in the text immediately following mention of important declarations, letters, papers, speeches and the like..$^{70}$ The intention may

\footnotetext{
${ }^{69}$ The listing of royal birthdays at the start of the journal is completely out of character with the rest of the work. Perhaps it was the result of an earlier abandoned project to keep a commonplace book.

${ }^{70}$ Reference numbers are provided in eighteen instances, although the first seven have been crossed out.
} 
have been to add later pertinent details from these sources, or possibly provide their text in appendices. Similarly, at four points in the journal there are significant blank sections which appear to be awaiting the addition of further text about Essex's I644 setback in the west, the king's 1645 letter to the Lords, the Scots' 1646 letter to parliament concerning the 'unknown knight', and the March 1646 address of a parliamentary delegation to common council. ${ }^{71}$ Furthermore, one written page of manuscript has been torn out of the journal..$^{72}$ This immediately follows a note about the interception by parliament of a letter from Edward Hyde in Jersey to the duke of Hamilton in Pendennis Castle, and perhaps originally contained further comment on that letter and its significance. There are a number of brief deletions and insertions in the journal, and at one point a passage of text is crossed out and a reworked text substituted. ${ }^{73}$ One page of text is inexplicably in a different hand and, on another page, there are two marginal references in red ink. ${ }^{74} \mathrm{~A}$ hand drawn in the margin occasionally points to a particular section of text.

There are three points at which Juxon goes over the same ground twice: the king's final escape from Oxford, the army officers' petition leading to the 'declaration of dislike', and the City's gaining of control over the militia. ${ }^{75}$ Otherwise Juxon writes economically in plain, if at times somewhat compressed and ungainly, prose with the odd ostentatious display of his knowledge of French and Latin and occasional displays of wit and gentle irony. He draws upon a Scottish term, for example, to mock the Scots' obsequiousness to their 'gend king', and in a similar vein refers to the 'twa kingdoms'. He also ridicules the obsession with social precedence that kept two princesses away from a wedding, 'such a hindrance is greatness to human society'. ${ }^{76} \mathrm{~A}$ clearly well-informed royal response to the City remonstrance of May ${ }_{1} 646$ 'seemed extreme luckily to favour' it, while Charles could not possibly 'desire the settlement of Presbytery out of love to it'."

There are occasional factual and other errors in the journal apart from chronological slips. Juxon consistently confuses Guernsey with Jersey and mistakes Cardigan for Cardiff, the earl of Callander for the earl of Crawford and Lindsay, a mythical 'Lord St Leger' for Lord Sinclair, and, more surprisingly, Henry IV for Henry VIII.$^{78} \mathrm{He}$ is wrong in his assertion

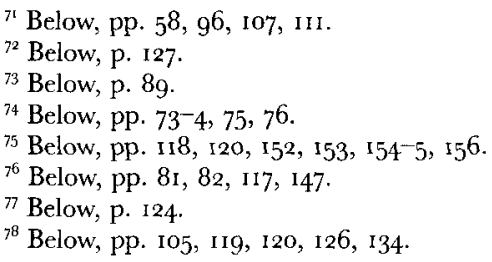


that the Independents were opposed to the execution of Sir John Hotham and in his estimate of the relative size of the opposing armies at Naseby ${ }^{79}$ $\mathrm{He}$ is also mistaken about the numbers of citizens subscribing the Presbyterian petition of March 1646 and the numbers of horse and foot desired by the Northern Association in April $1646{ }^{80}$ The purported conversation between the countess of Bedford and the king which Juxon carefully quotes has the appearance of fanciful hearsay. ${ }^{81}$ Yet such errors and uncorroborated reports are remarkably exceptional when set against the veracity and accuracy of the journal as a whole, and the obvious question arises: from where did Juxon derive his information?

Juxon would appear to have drawn upon a combination of public and private sources. One major source of information in the public domain was the constant stream of published material in the form of newsbooks, published letters, and printed accounts of battles and other key events. One general report of affairs begins 'For domestic news this week', and is followed shortly afterwards by 'We had also letters' introducing news about a military engagement. ${ }^{{ }^{2}}$ Phrases such as 'there came news', 'there came news likewise', or simply 'news came', introduce factual reports of events or actions. ${ }^{{ }_{3}}$ Cromwell's published letters furnished Juxon with details of the action taken against west country clubmen. ${ }^{84}$ The surrender of Bristol in September I 645 was 'as by the printed relations', and details of the battle of Philiphaugh were clearly derived from a published source. ${ }^{8_{5}}$ Other unpublished sources were of a semi-public nature, although some may eventually have reached the printing press. Juxon notes that parliament could rely on daily intelligence from Oxford, and he was apparently privy to some alarming fresh intelligence from royalist quarters which the parliamentary army committee hurriedly imparted to the London militia committee in April I646. ${ }^{86}$ A parliamentary agent, Monsieur Augier, provided regular intelligence from Paris on royalist intrigue in France, and Juxon apparently had some access to this correspondence. ${ }^{87}$ There are also suggestions, conveyed by the use of the phrase 'tis said', that some information was gleaned from current reports heard on the streets or in major gathering places such as the palace of Westminster, the

${ }^{79}$ Below, pp. 71 \& n. 186, 79-80 \& n. 228.

${ }^{80}$ Below, pp. $108 \&$ n. $353, \quad 116$ \& n. 394. There are a further five instances of completely wrong or inaccurate statements: below, pp. $43 \&$ n. 32, II $8 \&$ n. 4 oI, 121 \& n. $422,153 \&$ n. $581,157 \&$ n. 600 .

\footnotetext{
${ }^{81}$ Below, p. 82 \& n. 235

${ }^{82}$ Below, pp. 93, 94 .

${ }^{8}$ For example, below, pp. 99, 100 .

${ }^{8}$ Below, p. $8 \mathrm{I}$.

${ }_{5}^{8}$ Below, pp. 84,85 \& n. 253 .

${ }^{86}$ Below, p. 113 .

${ }^{87}$ Below, pp. II9-20.
} 
Guildhall or the Royal Exchange. As a Londoner Juxon could also observe what was being reported in Westminster and City-based committees. Finally, again as a London resident, he could personally witness events and report details about which other sources are silent. ${ }^{88}$

On a more private and conjectural level, Juxon had some important political contacts who could have furnished him with inside information. His uncle, Arthur Juxon, was a common councilman from 1643 to I645, and Thomas himself was closely acquainted with the Somerset MP, John Harington, who sat in the House from July 1646 onwards. Although Arthur Juxon probably did not serve on common council in I646-47 during those most eventful years in the City, his political contacts in the assembly would have been able to keep him and, through him, his nephew fully informed as to its political moods and major clashes. Thomas and his future wife, Elizabeth Carent, dined with Harington two days before he took his seat in parliament, and in the following August Harington sought his political advice. At the end of August, Harington conversed once again with Thomas and Elizabeth Carent prior to dining with the earl of Pembroke, and similar close contact between Harington and Thomas Juxon was to be maintained long after the period covered by the journal. ${ }^{89}$ In addition, Thomas may have been personally acquainted with such leading Independent figures as Vane, St John and Lord Wharton..$^{\circ}$

A final vital question that needs to be addressed is: when was the journal actually written? The answer is that it was almost certainly written after the events described, from notes taken at the time or from information gleaned subsequently. There are several pointers to this conclusion. Some of the chronological vagueness and the pattern of the errors in dating - especially how in many cases it is out by one day only - could be explained by the fact that it was not written on the day in question but afterwards. The blank sections may have been waiting for the addition of more text as the material was being organised for writing up. There are further clues in the text itself. There is Juxon's prescience with regard to the failure of Essex's expedition into the west in 1644 , as well as his reference to the war ending where it began, with conflict between England and Scotland. ${ }^{91}$ The reference to John Goodwin's contentious preaching in September 1644 fits into the chronological narrative, yet Juxon is also able to look ahead to

${ }^{88}$ For example, his report on the complicity of Alderman Bunce and some common councilmen in the invasion of the Houses in July 1647 , or his account of Scots commissioners badgering MPs on 2 August $\mathrm{r} 647$ : below, pp, $162,166$.

${ }^{89}$ Stieg (ed.), The diary of John Harington, MP, pp. 29, 32, 34, 46, 61, 68.

${ }^{90}$ Below, p. 94 \& n. 288.

${ }^{9}$ Below, pp. $5^{6-7}, 5^{8}, 6$ I, 78 . 
Goodwin's sequestration from his living in May $1645 \cdot{ }^{92}$ The journal concludes in August I647 with an account of Anthony Nicoll's confession, yet the first account of Nicoll's examination appears not to have been published until October $1647 .{ }^{93}$ Juxon's reference to his own marriage to 'my dear wife', ${ }^{94}$ rather than to his 'betrothed', also suggests that it was written up subsequently. The journal ends on the penultimate folio with the flight of the eleven members and the army in London. Could there possibly be a continuing volume taking matters through to the revolution of $164^{-}-49$ gathering dust in some private collection?

Its historical value There is much that is fresh and new in the journal which makes a significant contribution to an understanding of a complex period of political alignments and interrelated events. As a wellconnected and well-informed London resident, Juxon is a privileged source when it comes to shedding light on the normally half-hidden world of City politics, and explaining the intricacies of its political complexion and alliances. Similarly, as a keen and intelligent observer of events, at a national as well as a London level, he provides a valuable perspective on a political and religious world that is on course for transformation. New and controversial tools of political analysis are sometimes employed by Juxon as he seeks to make sense of this changing world, but more often the recourse is to a more conventional godly explanation. Finally, a good deal of space and detail is devoted to the wider power struggles and key events taking place in continental Europe, which are subjected to a similar combination of secular and godly analysis.

City politics Two important London subjects are elucidated by the journal - the internal politics of common council, and the wider organisation and tactics of the Presbyterian alliance in the capital. The latter embraced the political Presbyterians at Westminster, grouped around Essex, Holles and Stapilton, whose Presbyterianism was founded more on political expediency than religious conviction; and the High Presbyterians of the City - London's Presbyterian ministers led from Sion College and their civic allies (the 'covenant-engaged citizens'), who were committed to a church settlement on the Scottish model..$^{95}$ Juxon is the main source of knowledge about the common council's political divisions and its internal debates, which the assembly's formal

${ }^{92}$ Below, p. 6i \& n. 134.

${ }^{93}$ Below, pp. 169-70 \& n. 649 .

${ }^{94}$ Below, p. I50.

${ }^{95}$ The editors would like to thank Elliot Vernon for drawing their attention to the term 'covenant-engaged citizens' as the self-appellation of the High Presbyterian party in the City. 
records were designed to conceal from view behind an outward show of civic harmony. ${ }^{96}$ His analysis of the assembly's politics is grounded on the premise that majority opinion was decidedly more pragmatic than consistently partisan. Support for High Presbyterianism within common council was far from universal, and could never be taken for granted, as one of the votes on the controversial eldership ordinance of 20 October 1645 revealed, when, contrary to expectations, majority opinion was said to have endorsed Independent objections to allowing ministers the sole right to exclude parishioners from the communion. ${ }^{97}$ Common council in early I646, Juxon maintains, was a body within which a minority of party activists was able to impose its will on a silent and inactive majority. Thirty or forty supporters of High Presbyterianism were opposed outright by no more than five councillors, 'and the rest, who are the major part, are silent, as either not willing or not daring to appear; so a party carry on things there' ${ }^{98}$ However, faced with an unusually high level of attendance and the prospect of a headlong clash with parliament, as over the March ${ }_{1} 646$ petition, High Presbyterian councillors could lose the initiative and more moderate and conciliatory voices could prevail. Such an outcome convinced Juxon of 'the firm affection and inclination of the common council to the parliament, and that 'twas labour lost to attempt them' ${ }^{99}$ An attempt by militant Presbyterians a week later to revive the petition was defeated by the strong opposition of moderate councillors, and cordial relations were accordingly re-established between the City and parliament. ${ }^{100}$

Juxon is the main source of information for the little that is known

${ }^{96}$ Common council, the City of London's legislature, met in the Guildhall and was theoretically the representative body of all its freemen. Any freeman who was a ratepaying householder was eligible for election as a councillor and had to seek re-election each year. However, in practice councillors were usually drawn from among the more prosperous citizens and continued in office for successive years. Yet the common council elections of $\mathrm{I} 64^{\mathrm{I}}$ and, to a much lesser extent, those of ${ }_{1} 6_{42-}{ }^{-16}$ proved controversial, as efforts were made to unseat political opponents. Common council had a total membership of about 237 councillors in the mid-seventeenth century but, like its national equivalent, the House of Commons, levels of attendance could vary considerably depending on the political climate and the issues raised. Common councils were usually called about five or six times a year, while the City's executive body, the court of the lord mayor and aldermen, normally sat twice a week and exercised a careful control over the former. The particular circumstances of the 1640 s temporarily liberated common council from aldermanic control and led councillors to talk up the powers and privileges of their assembly, claiming that it was the representative body of the City. Juxon refers to common council in his journal as 'our representative body' and quotes examples of its presumption: below, pp. 102, 103, 122-3, 142.

${ }^{97}$ Below, pp. 89 go.

${ }^{98}$ Below, p. 106. In other words, Juxon is claiming that less than a fifth of the total membership of common council were openly and resolutely partisan.

${ }^{99}$ Below, pp. 109-10.

${ }^{100}$ Below, p. III. 
about the identities and activities of political Independents within common council. It is thanks to him that the seven Independent councillors who spoke out in the debate on the eldership ordinance of October 1645 are known. ${ }^{101}$ Similarly, he is the sole source of information on Stephen Estwicke's prominence in the attack on the City's remonstrance of May 1646, as well as on the leading role of Robert Tichborne among the eleven members who insisted on recording their dissent to the remonstrance when it finally came to a vote. Yet on this, as on other occasions, the information given by the journal can be tantalisingly incomplete. Two of Tichborne's fellow dissenters are named, but the identities of the other eight are not revealed. ${ }^{102}$ Likewise, it would be useful to know the identities of those councillors said to have played a part in the later petition of London Independents opposing the City's remonstrance, but no names are forthcoming. ${ }^{\text {103 }}$ The journal in April 1647 again notes Stephen Estwicke's leading role in resisting common council's attempts to force all members to retake the solemn league and covenant. It also fills in some of the detail about his violent expulsion from the assembly. Yet it is silent on the fact that John Brett, a fellow Independent councillor, had joined Estwicke in his recalcitrance. ${ }^{\mathrm{I04}}$

Some relatively rare details on debates within common council, or speeches to it, are to be found in the journal. There is illumination on the line of argument advanced by Independents against Presbyterian critics of the eldership ordinance of 20 October $1645 ;{ }^{\text {I05 }}$ the controversy sparked off on in February I 646 by the delivery of the letter from the Scottish parliament; ${ }^{106}$ and the debate on the following 20 May over the City's remonstrance. ${ }^{107}$ Furthermore, the journal is perhaps the only source for the content of the speech delivered by Samuel Browne, one of the parliamentary delegation to the assembly on 16 March $1646 .^{108}$

The journal is essential reading for anyone seeking an insight into the organisation and tactics of the Presbyterian alliance in London. Juxon is at pains to stress the behind-the-scenes influence exerted by London ministers in this context, but perhaps some allowance should be made for his strong anticlericalism before fully subscribing to his clerical conspiracy theory. The City petition of 20 September 1645 , complaining about the delay in settling Presbyterian church

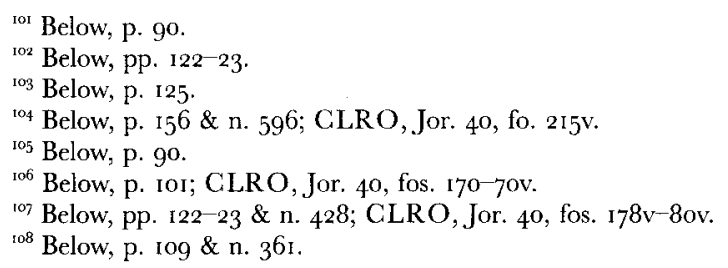


government, is described as having been 'fomented by the several ministers' ${ }^{109}$ London ministers are reported to have met together at Sion College to plan their attack on the Erastian nature of the eldership ordinance of 20 October 1645 . They decided to work covertly through common council against the ordinance. ${ }^{10}$ Presbyterian campaigning in the City continues during the following month, 'being stirred up and fomented by the ministers'. ${ }^{111}$ The latter are again 'the contrivers' of the Presbyterian campaign to canvass popular support in the wardmotes during common council elections at the end of the year. ${ }^{122}$ In early I646, ministers are still exerting considerable pressure on common council to push them 'forwards and make them active'. ${ }^{113}$ The passage of the measure appointing parliamentary commissioners to hear appeals against suspension from communion prompts ministers to send 'to their several agents in the City' to campaign against it. ${ }^{114}$ Yet Juxon is also careful to record instances when the London clergy faced setbacks in their City campaigning; for example, they are reported to have failed to win the immediate endorsement of their objections to the 1645 eldership ordinance from the common council committee set up to confer with them. ${ }^{115}$ Moreover, clericalist councillors were to have their hopes dashed when common council opposed granting ministers the sole right to exclude parishioners from the communion. ${ }^{116}$

There is also much valuable, and even previously unknown, information about the lay leadership of the Presbyterian alliance in the City, the tactics they adopted, and their wider political contacts. A Cheapside merchant, Lawrence Brinley, is identified as a key organiser of the City petition of 20 September I645, copies of which had been printed and circulated in every parish for signature by all who had taken the covenant. As with other Presbyterian petitions, the plan was to gain common council endorsement of the petition prior to its presentation to parliament. ${ }^{177}$ Juxon is particularly informative on the organisation of the City remonstrance of May 1646, and the high degree of coordination between City and parliamentary Presbyterians that lay behind it. He claims that the initiative for the remonstrance came from three leading figures in the earl of Essex's party - Sir Philip Stapilton, Lionel Copley and Edmund Harvey - and that after the text of the

\footnotetext{
${ }^{109}$ Below, p. 85 .

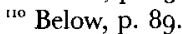

"1" Below, p. 95.

${ }^{112}$ Below, p. 97.

${ }^{13}$ Below, p. 103.

${ }^{14}$ Below, p. 108.

${ }^{115}$ Below, pp. 89 go.

${ }^{116}$ Below, p. 9o.

${ }^{17}$ Below, p. 85 .
} 
remonstrance had been approved by common council two prominent City Presbyterians, Captain John Jones and John Bellamy, sought Essex's advice on the timing of its presentation to parliament. ${ }^{118}$ The journal is probably the sole source of information about a dinner attended by several peers and MPs, as well as some aldermen and other citizens, on 23 June 1646 at the home of another leading London Presbyterian, Thomas Browne, 'wherein the design is mutually carried on'. ${ }^{\text {II }}$ The City's petition and engagement of 21 July 1647 is traced back to 'private meetings with all sort of persons' held in the city by the eleven impeached MPs. ${ }^{120}$ In addition, some senior City figures are charged with complicity in the force upon the Houses of 26 July; Alderman James Bunce, along with some common councillors and others, are described as acting as an organising committee in the Palace Yard for the coercion of parliament. ${ }^{121}$

There is also some rarity value in Juxon's exposure of the political struggles that accompanied several City elections. He adds to other evidence about Presbyterian plans to use the common council elections of 1645 to canvass popular support in the wardmotes for another petition to parliament. At the same time, there were coordinated sermons in every ward urging electors 'not to choose men of erroneous opinions'. But most novel are his claims that the petition gained only limited support, for 'in several wards it was cried up, and in many not, so that nothing came of it'; an accompanying handbill campaign likewise did little. ${ }^{122}$ The journal also confirms evidence from other sources that Independents fared badly in the common council elections of 1646 , while candidates with royalist leanings did well. The explanation offered is that the ferocity of the Presbyterian campaign to unseat Independents and their supporters was such that even some Presbyterians fell victim and found themselves replaced by known royalists. ${ }^{123}$ The surprise outcome of the mayoral election of September 1646 , when the neo-royalist Sir John Gayre emerged as the victorious candidate, is also carefully explained by Juxon as the result of a three-way split in the parliamentarian vote produced by Independent/Presbyterian hostilities. The analysis is the occasion for one of the few contemporary exposures of political tensions and voting patterns within the City's electoral body of common hall. ${ }^{124}$

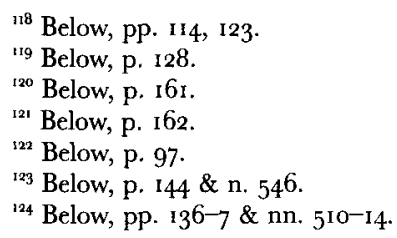


National politics In striving to make sense of the complex world of civil war politics, Juxon frequently resorts to the language of 'interest'. 'Seventeenth-century England', as Blair Worden has recently observed, 'saw a growing understanding of the extent to which politics is governed not by ethics or rights but by the "interests" of those who participate in it. ${ }^{125}$ The crown's perceived encroachment upon proprietorial interests during the early Stuart period probably did much to encourage this shift in outlook. Nevertheless, it was not until the early I640s that the theory and language of interest became common currency among political commentators. ${ }^{126}$ One of the most sophisticated exponents of this new political vocabulary was the civil war journalist, Marchamont Nedham. ${ }^{127}$ Drawing upon a study of interest theory and the nation state by the Huguenot grandee, the duc de Rohan, ${ }^{128}$ Nedham came to the view that the true or public interest could only be understood and served through the application of reason. ${ }^{129}$ The surest way to reach a settlement, he argued, was if the various political groupings royalists, Presbyterians, Independents etc. - abandoned all specious private ends and justifications and instead limited themselves to their rationally conceived or proper and 'peculiar' interests. Political stability, according to Nedham, did not demand that the parties sacrifice their particular objectives for the public good, as conventional wisdom dictated. Rather, it required the harmonisation of the parties' peculiar

${ }^{125}$ B. Worden, "Wit in a Roundhead": the dilemma of Marchamont Nedham', in S. D. Amussen and M. A. Kishlansky (eds.), Political culture and cultural politics in early modem England: essays presented to David Underdown (Manchester, 1995), p. 317. For the development and use of interest theory during the civil war period, see J. A. W. Gunn, Politics and the public interest in the seventeenth century (1969), ch. I; M. A. Kishlansky, 'Ideology and politics in the parliamentary armies, $1645-9$ ', in J. Morrill (ed.), Reactions to the English Civil War (1982), pp. 163-83; J. Scott, Algemon Sidney and the English Republic 1623-1677 (Cambridge, 1988), pp. 207-8; R. Tuck, Philosophy and government 1572-165I (Cambridge, 1993), pp. 222$3,228-40$.

${ }_{126}$ Gunn, Politics and public interest, pp. xi, $\mathrm{I}^{-}-3$.

${ }^{127}$ The following paragraph draws heavily upon the work of Worden and Gunn: 'Wit in a Roundhead', pp. 31 $7^{-19}$; Politics and public interest, pp. $47^{-8}$.

${ }_{128}$ The writings of the duc de Rohan influenced not only Nedham but also Algernon Sidney and a whole range of republican and Protestant theorists: Scott, Algernon Sidney, pp. 53, 76, 207; Gunn, Politics and the public interest, pp. $3^{6-8,48 .}$

${ }^{129}$ Worden has argued that reason was 'central to the political creed' of the classical republicans of the Interregnum. They saw politics as essentially 'a conflict between reason on the one hand and passion and will on the other. Popular sovereignty answered to reason: the hereditary principle embodied passion and will': Worden, 'Classical republicanism and the Puritan Revolution', in H. Lloyd-Jones, V. Pearl and B. Worden, eds., History and imagination ( $198 \mathrm{I}$ ), pp. 193-5. Juxon seems to have equated the royal interest, and perhaps 'greatness' generally, with irrationality (see below, pp. 23 n. 132, 29-30 \& $\mathrm{n}$. I88, I47), although whether he also shared the classical republicans' rationalist, Arminian leanings in religion is highly doubtful. 
interests - a process of political compromise and accommodation which Nedham referred to as a 'union of interests'.

Juxon was thus employing a novel and indeed controversial mode of discourse, ${ }^{130}$ although he rarely pursued the logic of interest into the Machiavellian territory sometimes explored by Nedham. ${ }^{13^{1}}$ Juxon certainly applauded 'rational proceeding', ${ }^{32}$ and was capable of taking a very dispassionate, Nedhamite view of politics; as at one point, for example, when commenting upon the Scots' alliance with the English Presbyterians: 'When the condition of the Scots is impartially considered, they had reason to apply themselves to the people and to make their party as strong as they could, else might the king and Independents have joined against them and they but left to shift for themselves.' Similarly, he maintained that the parliamentarians' failure to prevail against the king was attributable in part to their propensity for being 'false to our own interests'. ${ }^{134}$ These kind of pronouncements are reminiscent of the arguments used by Nedham in his more developed explications of interest theory. ${ }^{135}$ And like Nedham in such works, Juxon eschewed the use of biblical quotations to make his point. But generally speaking, he employed the language of interest within the more conventional framework of the politics of virtue. The result is a curious mixture of high political analysis in sceptical, Machiavellian strain (although the Florentine never used the term 'interest') and the moral perspective on public events of the godly. ${ }^{136}$ In common with many parliamentarian writers, Juxon interpreted the events of the civil war years as essentially a struggle between a public good, conceived in ethical and broadly puritan terms, ${ }^{137}$ and selfish, private interests. ${ }^{13^{8}}$

${ }^{13^{\circ}}$ The novelty of the language of interest for Juxon is underlined by his occasional use of the Italianate forms 'interesse' or 'intresse'. See Tuck, Philosophy and government, p. 223 .

${ }^{13 \mathrm{C}}$ The language of interest has been described by J. Scott as a 'sceptical and potentially ... "morally ambivalent" form of analysis': Scott, Algernon Sidney, p. 207.

${ }^{132}$ Below, p. 83. He dismisses the king and his advisers at Oxford as 'these men of strong fancies but bad intellects': below, p. 43 .

${ }^{133}$ Below, p. I47.

${ }^{134}$ Below, p. 74. Juxon at one point employed a similar line of argument with reference to the king: below, p. 79 .

${ }^{135}$ For example, a tract attributed to Nedham, Good English: or, certain reasons pointing out the safe way of settlement in this kingdom (8 May 1648 ), BL, E $44 \mathrm{I} / \mathrm{IO}$.

${ }^{136}$ For this blend of the Machiavellian and the puritan among mid-seventeenth century English radicals, see B. Worden, 'Milton's republicanism and the tyranny of heaven', in G. Block, Q. Skinner and M. Viroli (eds.), Machiavelli and republicanism (Cambridge, I990), pp. $230,232$.

${ }_{137}$ The struggle between private and public interest seems to be interpreted by Juxon in partly eschatological and providentialist terms as an aspect of God's 'extraordinary design' for the destruction of 'sensualities ... pomp, glory and greatness' and the setting up of a 'new monarchy': below, p. 89 .

${ }^{13^{8}}$ Gunn, Politics and public interest, pp. $6-7,3^{8}$. 
Thus at several points in his journal he implicitly contrasts the 'biased', 'particular', and self-serving interests of the king, the peerage, and the political factions in general, with the 'real happiness of the nation' and the 'common good'. ${ }^{139}$ The difficulty in reaching a settlement, he argues, was because 'everyone almost has sought himself and driven particular interest ... But now that all must be gathered up into one head (viz. salus populi) 'tis hard, nay impossible, that each particular should preserve his pretensions, but relinquish for the public good; and men being corrupt, here lies the difficulty'. ${ }^{140}$ Juxon, therefore, like many seventeenth-century radicals, clung to a rather traditional, moral view of what constituted the 'public good', while conceding that legal and constitutional forms could be overridden in the interests of the people. ${ }^{.41}$

Unlike Nedham, Juxon rarely used the term 'interest' to refer to the political factions themselves. ${ }^{{ }^{142}}$ In such cases he much preferred the more conventional and often pejorative label of 'party'. ${ }^{143} \mathrm{He}$ sometimes used the word party in its non-partisan sense, meaning simply a group or a part of the whole - thus he refers to 'the party of the Lords', 'the recorder and his party', 'the Lord Northumberland's party' etc. ${ }^{.44}$ But on several occasions, and particularly when referring to the royalists or the earl of Essex's supporters, his use of the term party carried more condemnatory overtones, being virtually synonymous with his most damning expression of political practice, 'faction' - by which he means the pursuit of selfish ends against the public good, or any group thus preoccupied. ${ }^{145}$ For example, he refers to both 'the party at Oxford' and 'the faction at Oxford' in very similar contexts. ${ }^{14^{6}}$ The growth of 'parties and factions' at Westminster, he opines, had 'extremely retarded the work'. ${ }^{147}$ And he clearly regarded the leaders of the 'covenantengaged' interest within common council as an especially 'violent' and

\footnotetext{
:39 Below, pp. 68, 72, 75, 76, 95, 98, го3, г 6 . He likewise contrasts 'bad and interested men' with the 'good and conscientious': below, p. 103. Juxon's belief that the pursuit of private interest and factional ends represented the greatest obstacle to the advancement of the common good was echoed by the New Model Army in the summer of I647: Kishlansky, 'Ideology and politics', in Morrill (ed.), Reactions to the English Civil War, pp. I $77-8$.

${ }^{14^{\circ}}$ Below, p. in6.

${ }^{141}$ Gunn, Politics and public interest, pp. 38-9; Tuck, Philosophy and government, p. 223; J. G. A. Pocock, The Machiavellian moment: Florentine political thought and the Atlantic republican tradition (Princeton, I975), p. 373.

${ }^{1} 4^{2}$ Juxon refers on two occasions to 'the Scots' interest', and once to 'the clergy interest': below, pp. 103, Iro, 124 .

${ }^{143}$ For a discussion of the various meanings which attached to the word 'party' during the 1640s, see Kishlansky, New Model Army, pp. 15-17.

${ }^{144}$ Below, pp. 43, 52, 57, 84, 147 .

${ }^{\text {I45 }}$ Below, pp. 49, 95, 106, I13, 116, I35.

${ }^{146}$ Below, pp. 40, 45 .

${ }^{147}$ Below, p. 7 o.
} 
factious grouping, even though he generally labelled them a party. ${ }^{14^{8}}$ Juxon's preference for the terms 'faction' and 'party', rather than the more neutral 'interest', when describing partisan groups is revealing. His view of politics was influenced at a basic level by the doctrine prevalent just a few years earlier of an organic political structure. The importance he attached to unity, particularly among parliamentarians, reflected more than simply a pragmatic acceptance that a divided house cannot stand. Unity, for Juxon, was almost a moral requirement. Certainly he equated the wilful breaking of that unity for private, immoderate ends with factionalism and a repudiation of the common good. ${ }^{149}$ Not even the parliamentary Independents, whose political objectives he generally approved of, escape his censure on this score..$^{150}$ Thus he castigated them for courting the ungodly party of the earl of Northumberland and deliberately squandering resources in Ireland merely to advance their 'faction'. ${ }^{151}$ However, insofar as the Independents' aims were broadly consistent with defeating the king and 'salus populi etc.', their partisanship was less reprehensible in Juxon's view than that of the peerage or Essex's supporters. Juxon was at his most disdainful when highlighting what he regarded as the wilfulness of Essex's party (particularly in blocking the establishment of the New Model Army) and its factional manipulation of parliamentary proceedings in concert with the Scots. ${ }^{152}$ The only true guardian of the public good, according to Juxon, was the 'honest' or 'godly party' 'party' here being used in its neutral sense of group. ${ }^{153}$ None of the nation's political constituents had driven 'less particular interests' than the godly party, or had served the commonweal more faithfully. ${ }^{154}$ During the war, he observes, not one member of the godly party had deserted parliament or betrayed their trust. ${ }^{55}$ Yet as the very term "the godly party' suggests, there was a partisan dimension to Juxon's

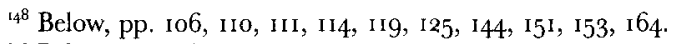

${ }^{149}$ Below, pp. 116, I35, I37.

${ }^{15 \circ}$ In March I645, Juxon comments that even though the younger Vane and Oliver St John favoured the Independent faction, they 'most sincerely do intend the real happiness of the nation'. Similarly, he implicitly contrasts the Independents with 'honest and ingenious men', and 'wise and good men': below, pp. 76, 103, 116, 117, 128, 135, 147.

${ }^{15 t}$ Below, p. 147.

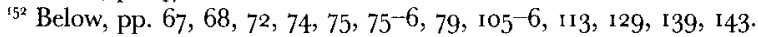

${ }^{153}$ Below, pp. $56,58,103,104,114$, I51. The meaning which Juxon attached to the term 'honest' in this context may well have derived directly, or at second hand, from Cicero and other classical writers, who equated it with what was 'utile', i.e. beneficial to human society and one's state, and the civic virtues of 'prudence, justice, temperance and fortitude': Tuck, Philosophy and govermment, pp. 7, 8. That Juxon seems to have used 'honest' and 'godly' interchangeably as political terms suggests that he saw the latter as being redolent of the same civic and humanistic virtues as the former.

${ }^{54}$ Below, p. 103 .

${ }^{155}$ Below, p. I04. 
conception of this group. Although occasionally he uses 'godly' or 'honest party' to apply to both the principal parliamentarian factions as distinct from the 'malignants' - that is, the royalists ${ }^{156}$ - more often than not he associates the term with the parliamentary Independents, or other opponents of the Scots and Essex's faction. ${ }^{157} \mathrm{He}$ evidently perceives a close affinity between the 'honest party' and the Commons (which for most of the period covered by the journal was dominated by the war party and pro-New Model Army factions): $:^{15^{8}}$ 'Now, and never till now, have they acted like the Commons of England and as such who (de jure) are to take care of the kingdom and revive there their almost obsolete maxim, salus populi etc. ${ }^{259} \mathrm{He}$ also lauds the 'active' men in the New Model as champions of the 'godly party', and when assessing Scottish politics he plumps for Argyle's hard-line covenanting faction as the only honest party in the kingdom. ${ }^{16 t}$

The journal reveals not only how Juxon thought about politics, but much about his political and ecclesiastical preferences, and it is interesting to note that these appear to feature the same mixture of the radical and the relatively conservative which he displayed in combining elements of interest theory and the politics of virtue. It is also evident that for all his disapproval of partisanship he was far from being a neutral observer of events. His highly critical stance towards the earl of Essex and his senior officers - the 'soldatesta faction' as he once refers to them ${ }^{162}$ - was closely in tune with the views of the so-called 'war party' at Westminster and its allies in the City. Like the 'fiery spirits' in the Commons and the City radicals, he suspected that Essex aspired to be a latter-day Sulla. ${ }^{163}$ Although he was scornful of Essex's martial abilities, at the same time he feared that the lord general intended to 'bring the parliament under the power of the army' ${ }^{164}$ Indeed, it seems that he was undecided where Essex's and Manchester's military incompetence ended and their machinations to advance their

${ }^{156}$ Below, pp. 137, 164 .

${ }^{157}$ Below, pp. 6I, 63, 103, I14, 151, 158. Although at one point he distinguishes between the 'honest party' in the Commons and the 'godly party' generally, he saw the former as defenders of the latter: below, p. 104.

${ }^{15^{8}}$ Below, pp. 75-6, 76, 77, I03, 104, II4.

${ }^{159}$ Below, p. 77.

${ }^{160}$ Below, pp. 8o, 86, 104-5.

${ }^{161}$ Below, p. I35.

${ }^{162}$ Below, p. 49 .

${ }^{163}$ From I642, argues John Adamson, Essex was directing 'a political campaign ... to confer upon himself protectoral rank and power', or the 'unlimited commission of a Roman dictator': J. S. A. Adamson, 'The baronial context of the English Civil War', Transactions of the Royal Historical Society, $5^{\text {th }}$ ser. 40, 1990, pp. I00, 108.

${ }^{164}$ Below, pp. $4^{2-3}, 4^{6}, 5^{2}, 55,5^{6}, 5^{8}, 60,63^{-5}, 74$. 
fellow 'grandees' and restore the king on easy terms began. ${ }^{165}$ Juxon's hostility towards Essex and his 'wicked' officers also extended, as has been seen, to the earl's political following at Westminster and in the City. On the other hand, he writes approvingly of the leaders of the war party - the younger Vane and Oliver St John ${ }^{166}$ - and looks upon the religious Independents in the parliamentary armies as 'the most active and brave men' in defence of the people's liberties. ${ }^{167}$

Where he clearly diverged from the war party, or at least its leadership, was in his opposition to the establishment of the committee of both kingdoms. ${ }^{168} \mathrm{He}$ disliked this body for the same reason he had its predecessor 'the committee for destruction, I mean safety'; ${ }^{\prime 69}$ that is, because he believed that it would encroach too much upon the authority of the Commons. 'There wants nothing now but a dictator' was his pessimistic comment after the first ordinance for the committee had been passed. ${ }^{70} \mathrm{He}$ also feared that the 'grand council of state' would give too much power to the Lords in matters of war and peace. Nevertheless, he was forced to acknowledge that 'the state of things considered, 'twas absolutely necessary to be done'. ${ }^{17}$ Moreover, his account of the committee's establishment, and particularly the opposition it aroused among those keen that 'his excellency [Essex] only should have the government and ordering of the. army', suggests that he may have seen it as partly an anti-Essex measure. ${ }^{172}$ This would perhaps explain his failure to sustain his criticism of the committee beyond early $\mathbf{1} 644$.

Some of Juxon's most critical remarks were reserved for the Scots which is perhaps hardly surprising given that they had very few genuine admirers in England, even among their parliamentarian allies. The Scots, in Juxon's view, were for the most part subtle, insinuating and greedy; a people raised on 'water and oatmeal', their loyalties fixed too much on their 'gend' (foolish) king, and possessed of a great desire to encroach upon the wealth, honour and power of their southern neighbour. ${ }^{173}$ In other words, Juxon harboured most of the anti-Scots prejudices typical of the early Stuart English. His attitude towards Scottish intervention in English affairs was more complex, however, and underwent several changes during the period covered by the

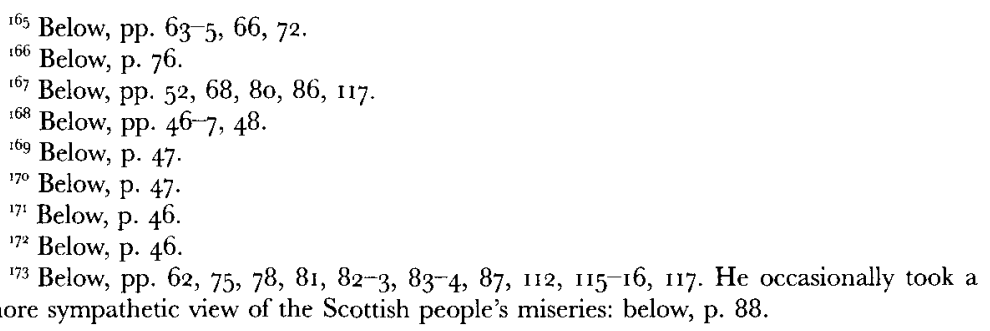


journal. In keeping with his war party leanings, Juxon welcomed the Scots' invasion of northern England early in I644 and repeatedly excused their failure to make greater headway against the marquess of Newcastle's forces. ${ }^{174}$ Significantly, Juxon's first harsh words about the Scots occurred at precisely the point at which the war party-covenanter alliance was beginning to break down. In the journal entries for October I644, he expresses disgust at parliament's willingness to 'crouch' to Scottish demands for suspending the accommodation order: 'Thus the Scots encroach upon us, [and] having a firm footing will now draw the curtain'. ${ }^{175}$ There then follows a lengthy aside on the Scots' cunning and duplicity. ${ }^{176}$ His distrust of the Scots was heightened following their alliance with Essex and his faction early in 1645 . Only when the plundering covenanter forces were destined to quit the kingdom, and their leaders had resisted the blandishments of the royalists and the French in delivering up the king to the English parliament, did Juxon resume a more friendly tone towards the Scots: 'The truth is, the Scots have discovered a very great constancy to their principles and engagements ... and filled their own kingdom with war and misery ... [which] must certainly draw from us a brotherly sense and assistance'. ${ }^{177}$ At various points throughout the journal, however, he praised certain individual Scots, notably the marquess of Argyle and men associated with his 'honest' party in Scotland, such as Alexander Leslie, earl of Leven, and Archibald Johnston of Wariston. ${ }^{178}$

Juxon's dislike of Scottish intervention in English politics had several causes. One was his contempt for the Scots' concern to maintain the king's prerogatives. Another, and perhaps the most important, was his aversion to the Scots' clericalism and their desire for a 'covenanted uniformity' between the two kingdoms. ${ }^{179}$ Similarly, he would have been disturbed at the covenanters' perceived willingness to don the bishops' mantle and persecute those who dissented from their views. ${ }^{180}$ When it came to settling church discipline and polity, Juxon was very much an Erastian. Parliament, in his eyes, should have the last word on such matters. ${ }^{18 \mathrm{r}}$ And, although at one point in the journal he portrays parliament's ecclesiastical policy as the product of statecraft, a delicate political balancing act designed to placate the factions, ${ }^{182}$ he evidently

${ }^{174}$ Below, pp. 44, 50. Juxon concedes that the Scots had come to parliament's aid 'in our necessity and have done us some good charges ... $\therefore$ below, p. 83 .

${ }^{175}$ Below, p. 61.

${ }^{176}$ Below, pp. 61-2.

${ }^{177}$ Below, pp. 133, 146.

${ }^{178}$ Below, pp. 122, I26, 128, I35, 140, 145 .

${ }^{179}$ Below, pp. 86, 87, 94, 99 .

${ }^{180}$ Below, p. 62.

${ }^{181}$ Below, pp. 6I, 86.

${ }^{182}$ Below, p. 86. 
felt that the Commons' resistance to 'government jure divino' was a wise and indeed moral principle. For MPs to establish jure divino Presbyterianism was in effect to dissolve the parliament and lose their privileges quite'. ${ }^{83} \mathrm{He}$ seems to have welcomed parliament's settling Presbyterian discipline in such a way as 'not to give any coercive power to them [the clergy] ... that all may not be in a confusion, but that those that will may be settled, like the enjoining the directory'. ${ }^{18}$ As these remarks suggest, Juxon was not concerned solely with the threat to English liberties posed by Scottish-style clericalism; he also regarded toleration by statute as 'opposite and destructive to any settlement of discipline'. ${ }^{85}$ 'God in his providence', he claims, had prevented the religious Independents from obtaining statutory liberty of conscience 'and suffered authority to set up Presbytery'. ${ }^{186}$ 'Confusion' and 'coercion' were both equally distasteful to Juxon, and he apparently felt that jure humano Presbyterianism, with de facto toleration for tender consciences, represented a godly middle course between these two evils. ${ }^{187}$

If Juxon was more or less in the mainstream of parliamentarian opinion on church government, when it came to settling the kingdom's divided civil polity he may well have favoured a more radical solution. Juxon was deeply antagonistic towards two of the three components of the ancient constitution - the king and the Lords. Indeed, he was hostile not just to Charles I and the English peerage, but to monarchs and lords in general: "Tis a miracle to see how the kings and lords are haunted with a malignity against Jesus Christ, as if his kingdom were incompatible with their tyranny, as indeed it is. Both cannot mutually flourish. ${ }^{288}$ Juxon's lengthy accounts of European affairs were partly

${ }^{18}$ Below, p. 106 .

${ }^{184}$ Below, pp. 86, 87, 89-9o, 95, гі9.

${ }^{185}$ Below, pp. 95-6. It would reveal much about Juxon's thinking on this issue if his reaction were known to the Cromwell-Saye group's attempts to introduce a bill in October 1647 giving limited toleration to Independent congregations and moderate Anglicans: J. S. A. Adamson, 'The English nobility and the projected settlement of 1647 ', Historical Joumal, 30 (1987), pp. 584-6; Adamson, 'Oliver Cromwell and the Long Parliament', in J. Morrill (ed.), Oliver Cromwell and the English Revolution, (1990), pp. 68-9.

${ }^{186}$ Below, p. 128.

${ }^{187}$ Those of the City aldermen who opposed the covenant-engaged faction were committed to an erastian Presbyterian church which preserved the parochial system while allowing limited toleration: M. Mahony, 'The Presbyterian party in the Long Parliament, 2 July $1644^{-3}$ June I647', (unpublished D.Phil. thesis, Oxford University, 1973), pp. 192 3.

${ }_{186}$ Below, p. $5^{\mathrm{I}}$. 'Greatness', according to Juxon, is 'a hindrance ... to human society' as well as being incompatible with Christ's kingdom: below, pp. 92, I47. Juxon, it seems, like Algernon Sidney and Milton, drew little distinction between monarchy and tyranny. Juxon and Sidney certainly perceived an increasing trend among continental princes to trample their people's interests in pursuit of dynastic and personal ambitions: Scott, Algemon Sidney, p. I96; Worden, 'Milton's republicanism', in Block, Skinner and Viroli (eds.), Machiavelli and republicanism, pp. 228-9. 
intended to demonstrate the folly of princes and the imminent downfall of 'tyranny and monarchia'. ${ }^{89}$ Like his radical contemporary, Sir Cheney Culpeper, he regarded the peerage as a 'private interest standing in the way of public good'. ${ }^{190}$ If the greatest faction in the kingdom was the king and his 'junto', then the Lords were not far behind. It is striking that Juxon never makes any effort to distinguish between Essex's supporters in the Lords and peers such as Viscount Saye and Sele who were prominent figures in the Independent party. ${ }^{191}$ Instead, he lumps all the parliamentarian nobility together under the label of 'the Lords and their party' little better than a royalist fifth-column: 'But that our (what do you call them) Lords are designed with their master, it would not be imagined they should act as they do', ${ }^{193}$ 'The king knows that the Lords are sure to him upon the interest of their peerage'; ${ }^{\text {t94 }}$ 'the Lords and their party ... certainly are agreed with the king and drive his interest, nor can do other'; 195 'The Lords and that party do much labour to hinder the army under the command of Sir Thomas Fairfax ... which appears whose interests they steer to, and how little they regard the real good of the nation, their peerage being their great idol'. ${ }^{196} \mathrm{He}$ has good words to say about only two English noblemen - the earls of Warwick and Northumberland ${ }^{197}$ - and his praise of the latter early in 1645 may merely reflect the fact that the earl had been conspicuous in his support for the New Model Army. ${ }^{198}$ Later in the journal Juxon criticises the Independents for courting 'the Lord Northumberland's party - whom

\footnotetext{
${ }^{189}$ Below, pp. $4^{8}, 9^{2}$. Thus the prince of Orange, in attempting to achieve absolute power, 'comes too late upon the stage to act that part'.

${ }^{590}$ Juxon and Culpeper would probably have seen eye to eye on a broad range of religious as well as political issues. Their differences were more of degree than kind. Thus Culpeper, a religious Independent, seems to have attached greater importance than Juxon to the benefits of toleration and freedom of conscience: M. J. Braddick and M.

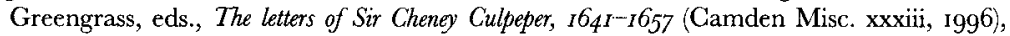
pp. $137-48$.

${ }^{19 r}$ The one exception to this rule occurs near the start of the journal when Juxon refers to 'the party of the Lords' who were enemies of the Scots: below, p. 43 .

${ }^{192}$ Below, pp. 67, 68, 72, 74, 75, I87.

${ }^{193}$ Below, p. 47.

${ }^{194}$ Below, p. 68

195 Below, p. 72

${ }^{196}$ Below, pp. 74, 75 .

${ }^{197}$ Below, pp. 57,76 .

${ }^{198}$ For Northumberland's role in the creation of the New Model, see J. S. A. Adamson, 'Of armies and architecture: the employments of Robert Scawen', in I. Gentles, J. Morrill and B. Worden (eds.), Soldiers, writers and statesmen of the English Revolution (Cambridge, 1998), pp. 36-67. Juxon is complimentary about only one European nobleman, the duke d'Enghien, whom he describes as 'a most gallant prince, a true gentleman' and, although a Catholic, 'very favourable' to the Protestant interest: below, p. 145 .
} 
they know are not godly'. ${ }^{199}$ His antipathy towards the king and peerage was strengthened by a millenarian conviction that God had marked their cause for destruction in anticipation of Christ's second coming. ${ }^{200}$ 'When He destroys the old,' Juxon declares, 'He will set up a new monarchy and bring in the desire of nations. ${ }^{201}$

Juxon's repeated denunciations of Charles and his nobility, and his belief that their tyranny was incompatible with the happiness of the kingdom, went well beyond the position of many contemporary writers that the two Houses were better able to determine the public interest than the king. ${ }^{202}$ Juxon's comments suggest that he conceived of little possibility of a lasting and well-grounded peace in which the king was restored to his prerogative powers or his legislative veto. Whether at the same time he favoured removing the Lords' negative voice is a more difficult question. Juxon probably agreed with the statement he attributed to the New Model Army grandees that 'though the people were rationally the supreme power, yet the parliament legally was'. ${ }^{203}$ But what exactly he means here is debatable. Did his reverence for the institution of the Commons as the ultimate guardian of the public interest ${ }^{204}$ extend to a conviction that parliament's sovereignty was inherent in its elective nature? ${ }^{205}$ To admit this is but a short step from labelling him a republican, which is even more problematic. Republicanism, as many historians have pointed out, is notoriously difficult to define. ${ }^{206}$ Yet if he indeed believed that the king and the Lords should lose their veto, or even be cut out of the legislative trinity altogether, then it would be possible to argue that he had republican leanings in the narrow, constitutional sense of wishing to vest supreme

${ }^{199}$ Below, p. 147. Warwick is also criticised later for persuading Lord Robartes to desert the 'better party': below, p. 84 .

${ }^{200}$ Below, pp. 89, 98, 121, 138, 145 .

${ }^{201}$ Below, p. 89.

${ }^{202}$ Tuck, Philosophy and government, pp. 228-30, 234; Scott, Algemon Sidney, p. 209. Juxon thought single person rule and the hereditary principle to be detrimental to the interests of the Dutch. Whether he thought the same with regard to the English is open to question: below, p. 92 .

${ }^{203}$ Below, p. 157.

${ }^{204}$ Below, pp. $5^{6}, 75^{-6,77}$.

${ }^{205}$ In other words, did Juxon agree with the New Model Army soldiers when they declared in June 1647 'this we speak of in relation to the House of Commons, as being entrusted in the peoples' behalf for their interest in that great and supreme power of the commonwealth, namely the legislative power, with the power of final judgement'? (cited in Kishlansky, 'Ideology and politics', in Morrill (ed.), Reactions to the English Civil War, pp. 174-5).

${ }^{206}$ See D. Wootton, 'The republican tradition: from Commonwealth to common sense', in Wootton (ed.), Republicanism, hiberty and commercial society, $1649^{-1776}$ (Stanford, 1994), pp. I-2; see also B. Worden, 'Marchamont Nedham and the beginnings of English republicanism, $1649^{-1656^{\prime}}$, in ibid., pp. 45-6; Tuck, Philosophy and government, p. 222. 
power solely in the people's elected representatives. ${ }^{207}$ What can be said with a little more certainty is that Juxon would have been generally out of sympathy with the Levellers. Not only was he opposed to toleration by law, but he seems to have been against any widening of popular participation in parliamentary politics. ${ }^{208}$ If Juxon's sometimes unwieldy synthesis of interest theory and proto-republican, or classical humanist, ideas was probably unusual among London's 'better sort' during the later I640s, his contempt for the 'multitude' and levelling ideas was far otherwise.

In addition to providing important insights into the development of political thought during the I64os, the journal contains a wealth of original material on key events and figures of the period. As a wealthy and well-connected London citizen, Juxon was ideally placed to observe the unfolding drama of civil war - much of which was played out in or near the City. A good deal of his information probably came from the vast array of 'printed relations' ${ }^{209}$ which poured from the London presses during the 1640 . But he also had contacts within the common council, the Commons and the Westminster Assembly. ${ }^{210}$ As a Londoner, he would likewise have had easy access to the lobbies of the Lords and the Commons, and, more importantly perhaps, to the Guildhall, which was the site not only of the common council, but also from 1646 of the army treasurers-at-war, and the committee of both Houses for the army. ${ }^{211}$ It was perhaps at the Guildhall that Juxon became familiar with Oliver St. John and other leading parliament-men. ${ }^{212}$ Juxon thus enjoyed a relatively privileged position among contemporary newsgatherers, and this is reflected in his journal. His comments on national and civic politics reveal hitherto unknown details about the careers of several important figures, and resurrect long forgotten incidents for which the journal seems to be the only extant source. For example, he provides a brief but colourful account of the first day's proceedings of the Oxford Parliament in January 1644, claiming that the debate

${ }^{207}$ Juxon is best described as a 'classical humanist' (to borrow Markku Peltonen's phrase) rather than a classical republican. Although not concerned specifically with constitutional forms, classical humanism, in its emphasis on 'civic consciousness', 'citizenship, public virtue and true nobility', provided many of the themes central to republican thinking during the 1640 os and 1650 s: M. Peltonen, Classical humanism and republicanism in English political thought ${ }_{1570-1640}$ (Cambridge, 1995), pp. 1-17, 31 1-12.

${ }^{208}$ Below, pp. 95-6, 102, 158 . Tuck has identified a number of political Independents during the 164 os who endorsed 'the principle of election and the supremacy of an elective assembly, though one without any "vulgar" participation': Tuck, Philosophy and government, pp. $235^{-} 40,247$.

${ }^{209}$ Below, p. 84 .

${ }^{210}$ Above, pp. 4, 7, 16.

211 Below, pp. 112, I13.

${ }^{212}$ Below, p. 94 . 
between Sir John Culpepper and his opponents grew so heated that 'twas believed they would have drawn' if the king had not arrived to break up the quarrel. ${ }^{213}$ Shortly thereafter the journal contains another fascinating revelation - that Fleetwood and Harrison quit the earl of Essex's lifeguard for the Eastern Association army as a result of a bitter quarrel with 'Stapilton and that party' arising from efforts by the City radicals to circumvent Essex's authority as commander-in-chief. ${ }^{214}$ The journal also provides fresh evidence concerning Lord Robartes's seemingly inexplicable defection to Essex's party in the summer of $1644^{215}$

Juxon applies a fairly broad brush to the political events of his day, but on those few occasions when he narrows his focus to report on proceedings in the Commons the journal often provides a unique glimpse of what would otherwise be long lost debates and exchanges on the floor of the House. He records how a Commons' speech by Sir Arthur Hesilrige in September I644 was vital in preventing John Glynne and his allies from punishing the radical City MP Isaac Penington for his negligence as lieutenant of the Tower of London. ${ }^{216}$ More importantly, Juxon's summary of Cromwell's address to the Commons on 25 November 1644 reveals much more personal detail about the speaker than any other surviving account of this speech. ${ }^{27}$ Juxon is also the only source to relate that the countess of Manchester invited Cromwell and the younger Vane over for supper the night before in an effort to take some of the heat out of their quarrel with her husband. ${ }^{218}$ Apparently Manchester and his allies were feeling rather more vulnerable at this point than some historians have credited. ${ }^{219}$ Certainly Juxon's claim that 'most men' in the City cried Cromwell up and Manchester down suggests widespread support among London's wellaffected for the campaign to new model the armies. ${ }^{220}$ Were it not for Juxon nothing would be known about important debates in the Commons on 20 February and 26 May 1646 concerning the City's links with the Scots. ${ }^{221}$ On two occasions the journal even cites hitherto unknown utter-

${ }^{213}$ Below, p. 43 .

${ }^{214}$ Below, pp. $15^{-2}$.

${ }^{215}$ Below, p. 84.

${ }^{216}$ Below, pp. 57-8.

${ }^{217}$ Below, p. 67. A. N. B. Cotton has speculated that Cromwell's relation of the 'effect and substance' of his narrative against Manchester was not a summary of the whole speech and probably excluded 'very important sections of it'. Juxon's own précis of Cromwell's words, which differs markedly from the printed summary, certainly supports this conclusion: A. N. B. Cotton, 'Cromwell and the self-denying ordinance', History, 62 (1977), pp. 217, 220.

${ }_{218}$ Below, p. 67.

${ }^{219}$ Cotton, 'Cromwell and the self-denying ordinance', pp. $21 \mathrm{I}^{-} 3^{-1}$.

${ }^{220}$ Below, p. 67.

${ }^{221}$ Below, pp. 103-4, 124-5. 
ances by the king: firstly to the countess of Bedford after his dash into the Eastern Association in August $1645{ }^{.222}$ and secondly to his council before he left Oxford in April $1646{ }^{223}$ But given that Juxon probably lacked the kind of privileged access to royalist sources that he had where parliamentary and civic affairs were concerned, both of these speeches can be regarded either as apocryphal or of doubtful authenticity.

Although the journal does little to alter the conventional image of Charles I or Cromwell, it considerably magnifies the importance of another key political player of the period, the Yorkshire MP Sir Philip Stapilton. Juxon implies that it was Stapilton who was the leading figure in Essex's faction in the Commons (at least until the lord general's death in September i646), not Denzil Holles, as most historians have assumed. Thus the journal refers to 'Stapilton and that party' and the 'Stapiltonian party'; Holles is rarely mentioned on his own and never accorded a factional following. ${ }^{224}$ Essex's death and that of Stapilton, thought Juxon, 'were the ruin of their party' ${ }^{225}$ It seems likely that the survival of Holles's Memoirs has exaggerated his importance as a party leader relative to that of Stapilton. Certainly as a legal adviser to Essex and captain of his life-guard, Stapilton would have been on more intimate terms with the lord general than Holles was. ${ }^{226}$ Moreover, unlike Holles, Stapilton was a member of the committee of both kingdoms - a position that would have given him sigrificant influence at Westminster in his own right. On a more general level, Juxon provides firm evidence of what Valerie Pearl, Michael Mahony and other historians of civil war London have often surmised, but never satisfactorily substantiated, and that is the close collaboration between the Essex-Stapilton party at Westminster and the 'covenant-engaged' citizens in the City. ${ }^{227}$

Besides adding a wealth of fresh detail to the narrative of the $1640 \mathrm{os}$, the journal offers a valuable new perspective on the political landscape of the period. Juxon is essential reading for anyone interested in the composition and evolution of parliamentary and civic political factions. His interpretation of the divisions at Westminster is broadly consistent with the view of David Underdown, Michael Mahony and several other recent historians that civil war parliamentary politics was based not upon a rigid two-party structure, but rather on the interaction

${ }^{222}$ Below, p. 82.

${ }^{223}$ Below, p. 120.

${ }^{224}$ Below, pp. 52, 84, I04, I54. It was Stapilton, claimed Juxon, who launched the attack in the Commons upon the New Model Army in July 1646: below, p. 131 .

${ }^{225}$ Below, p. 169 .

${ }^{226}$ V. F. Snow, Essex the rebel: the life of Robert Devereux, the third earl of Essex $1591-1646$ (Lincoln, Nebraska, 1970), pp. 203, 313.

${ }^{227}$ V. Pearl, 'London's counter-revolution', in G. E. Aylmer (ed.), The Interregnum: the quest for settlement $164^{6-1660}$ (1972), pp. 35-6, 38; Mahony, 'The Presbyterian party in the Long Parliament', pp. 206-7, 224-8, 330-I. 
between a number of bicameral alliances and interests. ${ }^{228}$ Juxon saw parliament and to a lesser extent its armies as being 'subdivided into so many factions that the public can scarce prosper'. ${ }^{229}$ When referring to divisions within the parliamentarians' ranks he sometimes does so in terms of a conflict between one or a combination of these factional interests and the public good as represented by the will of parliament or the desires of the 'honest', 'moderate', or 'godly party'. ${ }^{230} \mathrm{He}$ charts the emergence during the winter of $1644^{-} 5$ of a particularly potent alliance of interests - 'the assembly, the Lords and the Scots', 'the Presbyterian and lord general's and Scots' party', or the 'lord general's party ... the Scots and Presbytery' - which formed in opposition to new modelling the armies. ${ }^{231}$ Ranged against this alliance was another consisting of the 'Independent party' and anti-Essex officers, led by Cromwell, to which inclined the younger Vane, Oliver St. John and others of the 'moderate party'. ${ }^{232}$ Over the course of the journal, however, and particularly from early I645 onwards, he makes more frequent use of a dualistic model of parliamentary politics, often employing the familiar dichotomy of Presbyterians (or 'the Scots' party') and Independents. ${ }^{233}$ Whether this reflected an increasing homogenisation within the two main alliances or was simply a convenient short-hand is not made clear. Problems of interpretation are compounded by Juxon's use of the terms 'Presbyterians', 'Independents' etc. in reference to both political and religious groupings. In fact, he appears to draw very little distinction between the two in the case of either party. ${ }^{234}$ Admittedly, on the majority of occasions when the journal refers to 'Independents', it seems from the context that Juxon largely has religious Independents (often army officers or citizens) in mind. ${ }^{235}$ But it is often difficult from mid-1 645 to determine whether he is referring to religious Independents, their political allies, or both.

${ }^{228}$ Mahony, 'The Presbyterian party in the Long Parliament', p. 15; D. Underdown, Pride's Purge: politics in the Puritan Revolution (Oxford, 1971), esp. ch. 3; J. S. A. Adamson, 'Parliamentary management, men-of-business and the House of Lords, I640-49', in C. Jones (ed.), A pillar of the constitution: the House of Lords in British politics, $1640-17^{8} 4$ (1989), pp. $2 \mathrm{I}-5 \mathrm{o}$.

${ }^{229}$ Below, pp. 72, r04.

${ }^{230}$ Below, pp. 56, 58, 63, 68, 70, 76, 80, 84, 104, ro6. 'The Scots, the assembly, City, Lords, Stapilton's party, and malignants, their interests all meet in one upon several considerations against the godly party ...': below, p. I04.

${ }^{231}$ Below, pp. 68, 76, 79, 83 .

${ }^{232}$ Below, pp. 6r, 63, 75, 76 .

${ }^{233}$ Below, pp. 70, 89, 95, I12, І16, I17, I20, 125, I32, 135, 137, 144

${ }^{234}$ For examples of this confusion, or conflation, of meanings see below pp. 8o, 86, 94,95, I 2, I17, I33, I39, I 44 .

${ }_{235}$ Below, pp. 40, 43, 6r, 62, 70, 7I, 72, 75, 79, 85, 86, 95, I03, I23, I25, I58. For 'Presbyterians' and 'Independents' etc. as largely political labels, see below, pp. 75, 76, $83,88,147$. 
The historian who has made most use of the journal in recent years is Mark Kishlansky, who harnessed it very effectively to his thesis that the breakdown of parliamentary unity and the emergence of party politics did not occur until $1646-7 \cdot{ }^{236}$ The journal certainly supports Kishlansky's contention that the self-denying ordinance was a nonpartisan device for resolving the conflicts among parliament's senior officers, rather than (as some contemporaries and most historians have maintained) a stratagem advanced by the war party for removing Essex and his aristocratic allies from command. ${ }^{237}$ Juxon was aware, however, that the ordinance would strike most forcefully at 'the Lords and their party' by placing the army in the hands of men fully accountable to parliament. ${ }^{238}$ And in general the journal lends weight to the more established model of parliamentary political structure in the mid-I640s in which a clash between two parties, or two factional alliances, was the dominant theme by the winter of $1644^{-5}$ at the very latest. Westminster, in Juxon's account, was consumed by factional rivalry and the struggle between Presbyterian and Independent well before the showdown between army and parliament in 1647 .

The European context 'Foreign news is little welcome to the plebeian or vulgar sort of people, because they do not comprehend how much the present affairs of Christendom are interwoven and connected ... yet the meanest capacity may gather good fruit from the results, and see the evident hand of God in the actions and motions against the Protestants' enemies'. ${ }^{239}$ Like the author of The military scribe, Juxon thought foreign news a fruitful source for discerning the workings of Providence. This was implicit in his statement right at the beginning of the journal when he declares that 'Th'affairs of Europe respecting the Protestant party ... give great hopes that ere long the despised generation shall flourish' ${ }^{240}$ It is also likely that he shared the newsbook writer's

${ }^{236}$ Kishlansky, New Model Army.

${ }^{237}$ Below, pp. 69-70, 77; Kishlansky, New Model Amy, pp. 28-32. For the argument that the self-denying ordinance was a weapon designed by the war party for use against Essex and other aristocratic generals, see V. A. Rowe, Sir Henry Vane the younger: a study in political and administrative history (1970), pp. 55-7: L. Kaplan, Politics and religion during the English Revolution: the Scots and the Long Parliament I643-1645 (New York, I976), pp. 85-9; Gentles, pp. 6-Io. Mahony and others have argued in a similar vein, although with more emphasis on self-denial as a response of Cromwell and his allies to their vulnerability following the formation of the Presbyterian-Scottish alliance: M. Mahony, 'The Savile affair and the politics of the Long Parliament', Parliamentary History, 7 (1988), pp. 214 16; Cotton, 'Cromwell and the self-denying ordinance', pp. 2I I-31. Ashton's analysis of the self-denial initiative is broadly in line with that of Kishlansky: R. Ashton, The English Civil War: conservatism and revolution $1603-1649$ (1978), pp. 226-8.

${ }^{238}$ Below, pp. $6970,7^{2}$.

${ }^{239}$ The military scribe, (27 Feb. -5 Mar. I644), BL, E $35 / 21$, p. 16.

${ }^{240}$ Below, p. 39 . 
opinion that this subject was of little interest to the vulgar sort. The space and detail which he devotes to foreign affairs, his occasional inclusion of quotations in French, ${ }^{241}$ and the degree of knowledge of overseas events and figures he assumes on the part of his intended readership, are further confirmation that he was writing for a reasonably well-educated, wellinformed and thus (on the whole) well-to-do audience. He probably acquired some of his information from newsbooks, particularly those such as The weekly accompt or The moderate intelligencer which tended to dwell at greater length than their rivals on European affairs. However, it is clear that he had other, more arcane, sources at his disposal. His disclosures concerning the Prince of Orange's bed-chamber politics, ${ }^{2{ }^{2}}$ for example, or his account of the voting patterns in the Scottish parliament, ${ }^{243}$ do not appear in any of the newsbooks, and it is likely that he obtained material more directly, via his contacts among the London mercantile community, or simply through gossiping on the Royal Exchange.

Juxon seems to have prided himself on his ability to eludicate the Byzantine workings of continental high politics. The picture he paints of European affairs was one in which self-interested factions and rulers ruthlessly vied for power by whatever means available. ${ }^{244}$ Broadly speaking, he organises his material around three main, and closely connected, themes: the struggle between the 'Protestant party' and the 'Jesuited papist' faction, the rivalry of Habsburg versus Bourbon and the host of lesser quarrels it subsumed, and the king's vain attempts to work around these conflicts in order to secure military and financial support against his domestic opponents. ${ }^{245}$ When recounting foreign news Juxon sometimes adopted the air of analytical detachment which Machiavelli had made popular among writers on international relations. ${ }^{24^{6}}$ Indeed, at one point he uses that most Machiavellian of phrases, 'reason of state', and acknowledges it as a valid warrant for princes, even when it extended to the execution of dynastic rivals. ${ }^{247}$ But underlying reason of state and the 'pomp, glory and greatness' of princes Juxon perceives a more powerful force at work - the unfolding of God's great design of destroying the carnal and tyrannical monarchies of man and establishing His 'new monarchy' that would 'bring in the desire of nations'..$^{28}$ Closely linked in Juxon's mind with Christ's

${ }^{241}$ Below, pp. $78,112,136$.

${ }^{242}$ Below, pp. 52, 92-3, $146-7$.

${ }^{243}$ Below, pp. 135, I45.

${ }^{244}$ Below, pp. $45^{-6,78,88,146-7}$.

${ }^{245}$ Below, pp. 45, 46, 47 8, 52, 88, 90-1, 106, I12, I29-30, 131-2, 136, 144-5, 146-7, I49, 153 .

${ }_{24}^{46}$ Below, pp. $45,4^{6}$

${ }^{247}$ Below, p. 72.

${ }^{248}$ Below, p. 89 . 
imminent second coming were the endeavours of Europe's peoples, the English included, to frustrate the absolutist tendencies of their rulers. ${ }^{249}$ 'This seems to be clear', he wrote, 'that their governments are generally so tyrannous and insupportable that, besides God's design, they do bespeak their own ruin. ${ }^{225}$ The civil war in England was for Juxon just one theatre in a European-wide conflict between the forces of AntiChrist and the 'despised generation' - a group which seems to have included not only the Protestant party but the oppressed peoples of Christendom in general.

\section{Editorial decisions and practices}

The main aim has been to provide a clear text of the journal with a view to making it as accessible as possible. Hence, abbreviations have been expanded and spelling, the use of capitals, punctuation and paragraph structure have generally been modernised. The major exceptions to this practice have been the retention of the original variant spellings of the word 'interest' as well as the latinised forms of some other words, and Juxon's deliberate use of the Scottish term 'twa' for 'two', where a particular significance is attached to the spelling. Translations have been provided in footnotes for passages in French or Latin in the text or appendices. The editors have also made insertions into the text enclosed within square brackets to help clarify the syntax or to provide essential information. Dates are in the 'old style' except that the new year it taken to begin on the I January. In order to ease chronological reference, dates given in the text are highlighted in bold type. Furthermore, footnotes are used to provide the precise dates of actions or events noted in the text and to correct faults in Juxon's own dating.

The notes and references to dates which Juxon periodically provides in the margins of the journal are distinguished from the rest of the text by being placed within angled brackets $<>$. Words crossed out, substituted or interlined in the journal are underlined and explained. Folio references to the original text are contained within square brackets. London is the place of publication of works cited in footnotes unless otherwise stated.

\footnotetext{
${ }^{249}$ Below, pp. 92, $13^{2 .}$

${ }^{25^{\circ}}$ Below, p. $9^{2}$.
} 